\title{
Agronomic Evaluation of Wheat (Triticum aestivum L.) Under Certified Organic Production System
}

\author{
M. Shiva Kumar*, Rajesh Singh and Punnam Chhetri
} Department of Agronomy, Sam Higginbottom University of Agriculture, Technology and
Sciences, Prayagraj-211007, Uttar Pradesh, India

*Corresponding author

\section{A B S T R A C T}

\begin{tabular}{l} 
Ke y w o r d s \\
Organic, Wheat, \\
FYM, \\
Vermicompost, \\
Panchagavya, \\
Vermiwash, Grain \\
\hline Article Info \\
\hline $\begin{array}{l}\text { Accepted: } \\
12 \text { November } 2020 \\
\text { Available Online: } \\
10 \text { December } 2020\end{array}$ \\
\hline
\end{tabular}

A field experiment was conducted during winter Rabi season of last week of December 2019 at the certified organic experiment farm of the SHIATS Model of Organic Farm (SMOF) in NAI, Prayagraj to study the response of wheat under different sources of organic manures and liquid organic formulation on yield attributes of wheat (Triticum aestivum L.). The experiment consists of 10 treatments with 3 replications laid out in a randomized block design. Organic manures i.e. Control $16 \mathrm{t} / \mathrm{ha}, \mathrm{M} 1$ : FYM $25 \%(4 \mathrm{t} / \mathrm{ha})+$ Vermicompost 75\% (4.5 t/ha), M2: FYM 50\% (8 t/ha) + Vermicompost 50\% (3 t/ha), M3: FYM 75\% (12 t/ha) + Vermicompost 25\% (1.5 t/ha) and Liquid organic formulations i.e. L1: Panchagavya at 2\%, L2: Vermiwash at 5\%, L3: Panchagavya at 2\% + Vermiwash at $5 \%$. The result concluded that the treatment T2-FYM 25\% +VC 75\% + Panchagavya at $2 \%$ spray, recorded highest plant height $(78.21 \mathrm{~cm})$ and T4 - FYM $25 \%+\mathrm{VC} 75 \%+$ Panchagavya at $2 \%+$ Vermiwash at $5 \%$ spray, there was significant and higher number of grains/ spike (41.34), effective tillers hill (5.11), test weight (37.32 g) and same treatments recorded higher grain yield $(3.29 \mathrm{t} / \mathrm{ha})$, straw yield $(4.51 \mathrm{t} / \mathrm{ha})$. This indicates that combination of organic manures with FYM 8 t/ha +VC 3 t/ha + Panchagavya $2 \%$ spray is important to get higher wheat yield from organic production system.

\section{Introduction}

Wheat (Triticum aestivum L.) is the world's most outstanding crop that excels all other cereals both in area and production, also known as king of cereals. Its grown throughout the temperate, tropical and subtropical region in the world. It constitutes the staple food in at least 43 countries. Maximum area under wheat is the China followed by India, Russian Federation and USA. India occupy second position in world wheat cultivation. India cover 295.76 lakhs of hectares area, production is 99.70 million tonnes $(12.32 \%)$, yield $3371(\mathrm{~kg} / \mathrm{ha})$. Three largest producing states of India, Uttar Pradesh 31.88, Punjab 17.85, Madhya Pradesh 15.91 during 2018-19 year. (Directorate of Economics \&Statistics, DAC\&FW, 2018-19).

The prolonged and over-use of chemicals than 
crop requirement resulted in human health hazards and imbalance in natural resources. In this context, a keen awareness has to be created on the adoption of organic farming as a remedy to maneuver the ill-effects from chemical farming. The total nutritional consumption (NPK) from chemical fertilizers is about 25.54 million tonnes (Department of Fertilizers, 2012-13) in India.

FYM or well decomposed compost at the 5 to $10 \mathrm{t} / \mathrm{ha}$ every year is helpful in maintaining soil health, increases the availability of nutrient and reduces toxic effects of chemicals and fertilizers. Green manure using dhaincha (Sesbania aculeata L.) or sunnhemp (Crotalaria juncea L.) will promote sustainability in the rice-based cropping system (Abraham et al., 2002). Vermicomposting is the process of producing compost by utilizing earthworms to turn the organic waste into high- quality compost that consists mainly of worm cast in addition to decayed organic matter (Devi and Prakash 2015). Vermicompost can improve food quality without compromising with food safety (Simsek-Ersahin 2011).

Agrawal et al., (2010) concluded that application of VC and FYM in combination also showed effect on yield parameters i.e., number of spikes/plants, number of seeds/spikes, test weight, harvest index (HI) and yield/plot were recorded maximum and the magnitude of increase $\mathrm{HI}$ and grain yield was $39.67 \%$ and $2.80 \mathrm{~g} / \mathrm{plot}$ respectively.

Role of foliar application or seed soaking of panchagavya in production of many plantation crops had been well documented in India. These organic formulations contain all the trace elements and some essential plant growth hormones. Natural plant growth regulators (e.g. Auxin, Gibberellin and cytokinin) present in these liquid organic formulations give a major boost to crop yields by accelerating the plant's metabolic function. Presence of macro (N, P, K and $\mathrm{Ca}$ ) and micro ( $\mathrm{Zn}, \mathrm{Fe}, \mathrm{Cu}$ and $\mathrm{Mn}$ ) nutrients besides total reducing sugars (glucose) in Panchagavya. Chemolithotrops and autotropic nitrifiers (ammonifers and nitrifers) present in Panchagavya which colonize in the leaves increased the ammonia uptake and enhance the total $\mathrm{N}$ supply (Papen et al., 2002) and (Swaminathan et al., 2007).

Hence, the present investigation was carried out to study the agronomic evaluation of wheat (Triticum aestivum L.) under certified organic production system.

\section{Materials and Methods}

Exhaustive wheat crop experiment was taken in rabi season during 2019-2020 on a sandy clay loam at certified organic farm, SMOF. [SMOF was developed under the National Project on Organic Farming (NPOF) by the department of Agronomy, with Dr. Thomas Abraham, Professor (Agronomy) as it's Principal Investigator. The 2 hectares area has been certified by Lacon Quality Certification (P) Ltd, (Accreditation by Ministry of Commerce, Govt. of India). Naini Agricultural Institute, Sam Higginbottom University of Agricultural Technology and Sciences, Prayagraj.

Climate of the region is sub-tropical and semi-arid climate with the monsoon commencing from July and withdrawing by the end of September. For the intended study 10 treatments were tested under three replications by using randomized block design. Three organic manures viz. Control FYM 16 t/ha, M1: FYM 25\% (4 t/ha) + Vermicompost $75 \%$ (4.5 t/ha), M2: FYM $50 \%(8 \mathrm{t} / \mathrm{ha})+$ Vermicompost 50\% (3 t/ha), M3: FYM 75\% (12 t/ha) + Vermicompost $25 \% \quad(1.5 \mathrm{t} / \mathrm{ha})$ and Liquid organic formulations viz. L1: Panchagavya at 2\%, L2: 
Vermiwash at 5\%, L3: Panchagavya at 2\%+ Vermiwash at $5 \%$. The farm yard manure and vermicompost doses were mixed in the soil before sowing and vermiwash and panchgavya were used as foliar application on the crop at 20, 40 and 60 DAS. The wheat variety K-7903 (HALNA) was selected for experiment. The seeds were sown by line sowing with the spacing of $22.5 \mathrm{~cm} \times 10 \mathrm{~cm}$. Seeds were treated using luke warm water followed by dipping the $5 \mathrm{~kg}$ of seeds in 10 litre of luke warm water to remove lighter seeds and impurities.

\section{Results and Discussion}

\section{Plant height (cm)}

Plant height at 100 DAS, there was a significant increase of plant height $(78.21 \mathrm{~cm})$ in T2 (FYM 25\% +VC 75\% + Panchagavya $2 \%$ spray). However, T3 (FYM 25\% +VC $75 \%$ + Vermiwash 5\% spray) and T4 (FYM $25 \%+\mathrm{VC} 75 \%+$ Panchagavya at $2 \%+$ Vermiwash at $5 \%$ spray) were statistically at par with $\mathrm{T} 2$.

Application of organic manures shows remarkable improvement in plant height. This might be due to higher nutrient supply of Farm Yard Manure (FYM), Vermicompost (VC), they provide nutrients for longer period and readily available form with growth promoting substance which improve overall growth. Similar results were found by Patil and (Bhilare 2000), (Channabasanagowda et al., 2008), (Aulakh et al., 2018). Spraying of panchagavya at tillering and jointing stage, plant height was significantly increased plant height due to growth hormones present in panchagavya, which help in cell division and elongation (Sanjutha et al., 2008).

\section{Plant dry weight (g)}

Plant dry weight at 100 DAS was recorded highest $(20.63 \mathrm{~g})$ in T4 (FYM 25\% +VC 75\%
+ Panchagavya at $2 \%+$ Vermiwash at $5 \%$ spray). However, T3 (FYM 25\% +VC 75\% + Vermiwash at 5\% spray) and T2 (FYM 25\% $+\mathrm{VC} 75 \%$ + Panchagavya at $2 \%$ spray) were statistically at par with $\mathrm{T} 4$.

Combination of VC and FYM application helps to increase total biomass production in dry weight of plant (Agrawal et al., 2003). It was observed that with an application of FYM $+\mathrm{VC}$ and organic liquid manure, they stimulate vegetative growth of crop, help to increase maximum plant dry weight (20.63 $\mathrm{g} /$ plant) was recorded in wheat. Exclusive application of VC, FYM strengthening wheat growth characters.

Result indicated available of essential micronutrients, less incidence of pest attack and favored to increase the dry weight of plant. Same result was found (Suhane et al., 2008; Sinha et al., 2009). Organic manures make easily available of nutrients to crop without any losses (leaching, runoff), nutrient uptake will increase, ultimately dry matter accumulation significantly increases (Gurwinder Singh et al., 2018; Mubarak and Singh, 2011).

\section{Grains/ Spike}

The highest number of grains per spike were recorded (41.34) significantly high in $\mathrm{T} 4$ (FYM 25\% +VC 75\% + Panchagavya at 2\% + Vermiwash at $5 \%$ spray) over control. However, T2 (FYM 25\% +VC 75\% + Panchagavya at $2 \%$ spray), T3 (FYM 25\% $+\mathrm{VC} 75 \%+$ Vermiwash at 5\% spray), T5 (FYM 50\% +VC 50\% + Panchagavya at 2\% spray), T6 (FYM 50\% + VC 50\% + Vermiwash at 5\% spray), T7 (FYM 50\% + VC $50 \%$ + Panchagavya at $2 \%$ + Vermiwash at 5\% spray), T8 (FYM 75\% + VC25\% + Panchagavya at $2 \%$ spray) and T10 (FYM $75 \%+\mathrm{VC} 25 \%+$ Panchagavya at $2 \%+$ Vermiwash at $5 \%$ spray) were statistically at par with T4 (Table 1). 
Table.1 Effect of organic manures on growth and yield of wheat viz Grains/spike Effective tillers/hill, Test weight

\section{Treatment combinations}

1 Control

2 FYM $25 \%+$ VC $75 \%$ + Panchagavya at $2 \%$ spray

3 FYM $25 \%+\mathrm{VC} 75 \%+$ Vermiwash at $5 \%$ spray

4 FYM 25\% +VC 75\% + Panchagavya at 2\% + Vermiwash at 5\% spray

5 FYM 50\% +VC 50\% + Panchagavya at 2\% spray

6 FYM 50\% + VC 50\% + Vermiwash at 5\% spray

7 FYM 50\% + VC 50\% + Panchagavya at 2\% + Vermiwash at 5\% spray

8 FYM $75 \%+$ VC25\% + Panchagavya at 2\% spray

9 FYM $75 \%+$ VC $25 \%+$ Vermiwash at $5 \%$ spray

10 FYM $75 \%+$ VC 25\% + Panchagavya at 2\% + Vermiwash at 5\% spray

$$
\mathrm{F} \text { test }
$$$$
\operatorname{SEm}( \pm)
$$

$\mathrm{CD}(\mathrm{P}=0.05)$

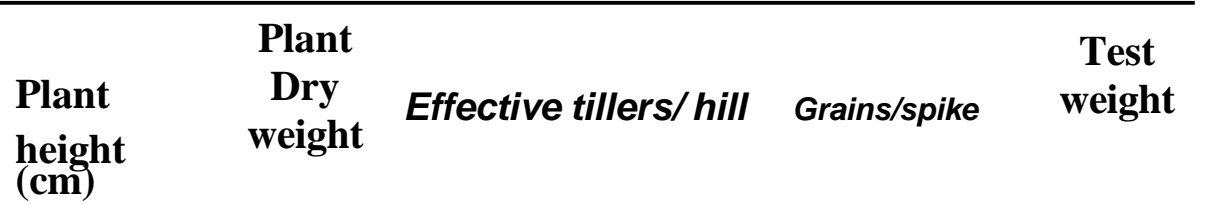

(g)

$61.77 \quad 15.19$

$78.21 \quad 18.99$

$76.53 \quad 19.55$

$76.03 \quad 20.63$

$72.8 \quad 18.44$

69.41

18.49

67.38

17.86

63.21

16.96

62.45

16.7

$65.1 \quad 17.51$

$\mathrm{S}$

0.74

$\mathrm{S}$

0.69

2.69
4.72
5.02
5.11
3.96
3.89
3.78
3.47
2.96
3.71
$\mathrm{~S}$
0.23

(g)

27.58

33.03

40.33

35.87

40.93

36.42

$41.34 \quad 37.42$

$39.71 \quad 35.02$

39.47

34.9

$39.34 \quad 33.84$

$38.46 \quad 33.61$

$36.09 \quad 32.97$

$39.14 \quad 33.73$

$\mathrm{S}$

$\mathrm{S}$

1.37

0.54 
Table.2 Effect of organic manures on growth and yield of wheat yield attribute characters viz., Grain yield and straw yield

\begin{tabular}{|c|c|c|c|}
\hline & Treatment combinations & Grain yield (t/ha) & Straw yield (t/ha) \\
\hline 1 & Control & 1.61 & 2.75 \\
\hline 2 & FYM $25 \%+$ VC $75 \%+$ Panchagavya at $2 \%$ spray & 2.95 & 4.20 \\
\hline 3 & FYM $25 \%+$ VC $75 \%+$ Vermiwash at $5 \%$ spray & 3.15 & 4.32 \\
\hline 4 & FYM $25 \%+$ VC $75 \%+$ Panchagavya at $2 \%+$ Vermiwash at $5 \%$ spray & 3.29 & 4.51 \\
\hline 5 & FYM $50 \%+$ VC $50 \%+$ Panchagavya at $2 \%$ spray & 2.75 & 3.95 \\
\hline 6 & FYM $50 \%+$ VC $50 \%+$ Vermiwash at $5 \%$ spray & 2.60 & 3.84 \\
\hline 7 & FYM $50 \%+$ VC $50 \%+$ Panchagavya at $2 \%+$ Vermiwash at $5 \%$ spray & 2.43 & 3.67 \\
\hline 8 & FYM $75 \%+$ VC25\% + Panchagavya at $2 \%$ spray & 2.16 & 3.33 \\
\hline 9 & FYM $75 \%+$ VC $25 \%+$ Vermiwash at $5 \%$ spray & 2.08 & 3.22 \\
\hline \multirow[t]{4}{*}{1} & FYM $75 \%+$ VC $25 \%+$ Panchagavya at $2 \%+$ Vermiwash at $5 \%$ spray & 2.39 & 3.67 \\
\hline & F test & S & $\mathbf{S}$ \\
\hline & $\operatorname{SEm}( \pm)$ & 0.07 & 0.11 \\
\hline & $\mathrm{CD}(\mathrm{P}=\mathbf{0 . 0 5})$ & 0.22 & 0.32 \\
\hline
\end{tabular}


Use of FYM and VC, highest number of grains accrued (Neelam 2015). The sink capacity of a plant depends mainly on vegetative growth of the plant which is affected positively by application of nitrogenous fertilizers and supply of photosynthates for the formation of yield components. Similar observations were reported by (Patel and Upadhyay 1993).

\section{Effective tillers per hill}

Number of Effective tillers/hills observed significantly higher over the control. Among the treatments, highest number of effective tillers/hills were recorded (5.11) in T4 (FYM $25 \%+\mathrm{VC} 75 \%+$ Panchagavya at $2 \%+$ Vermiwash at 5\% spray). However, T2 (FYM $25 \%+\mathrm{VC} 75 \%+$ Panchagavya at $2 \%$ spray) and T3 (FYM 25\% +VC 75\% + Vermiwash at $5 \%$ spray) were statistically at par with $\mathrm{T} 4$.

Applied organic manures created favorable soil environment, which leads to increase water holding capacity of soil for long time. Ultimately number of effective tillers/hills increased (Sandeep et al., 2018). Better utilization of FYM and panchagavya, present growth hormones which improve yield attribute characters i.e. effective tillers spike (Pagar 2016).

\section{Test weight (g)}

The perusal of the data clearly indicates that the highest test weight was recorded (37.42) under the T4 (FYM 25\% +VC 75\% + Panchagavya at $2 \%+$ Vermiwash at $5 \%$ spray). However, T2 (FYM 25\% +VC 75\% + Panchagavya at 2\% spray) and T3 (FYM 25\% $+\mathrm{VC} 75 \%+$ Vermiwash at $5 \%$ spray) were statistically at par with T4.

Improvement of test weight might be due to proper utilization organic manures, enhance sustainable production of crop. Same data found in two consecutive year research work (Tolera Abera et al., 2018). Test weight of wheat increased significantly with FYM, VC, poultry manure and green manure incorporation helped to achieve desire result (Sandeep Kumar and Thomas Abraham 2018) (Table 2).

\section{Grain and Straw yield}

The data revealed that there was a significant increase of grain yield using organic manures. The highest grain yield (3.29 t/ha), straw yield $(4.51 \mathrm{t} / \mathrm{ha})$ was observed in treatment $\mathrm{T} 4$ (FYM 25\% + VC 75\% + Panchagavya at 2\% + Vermiwash at 5\% spray). However, Desire yield is achieved through effective utilization of FYM, VC, liquid organic formulations and green manures incorporation.

Under organic production, Organic sources of nutrients are the best option to maintain the health of soil, provide the equal opportunity for all living existence to live and use from their beneficial activities, like nitrogen fixation, phosphorus solubilization, recycling of animal waste and green manure. Use of FYM $25 \%+$ VC $75 \%$ + Panchagavya at 2\%+ Vermiwash at 5\% spray, found better result in yield attributes like grain yield and straw yield. Similar result found (Tamim Fazily and Hunshal 2010), (Davari et al., 2007), (Pagar et al., 2016 b).

From the experimental findings, it can be concluded that the application of FYM $25 \%$ $+\mathrm{VC} 75 \%+$ Panchagavya at $2 \%+$ Vermiwash at $5 \%$ spray, resulted higher grain yield up to $48 \%$ over control.

\section{Acknowledgement}

I express gratitude to my advisor Dr. Rajesh Singh for constant support and guidance. I am indebted to Prof. (Dr.) Joy Dawson, Prof. (Dr.) Thomas Abraham, Dr. Vikram Singh, 
Dr. Umesha. $\mathrm{C}$ and all the faculty members, Department of Agronomy.

\section{References}

Anonymous. (2012-13). Statistics, All India Area, production and yield of wheat (Triticum aestivum L.). Directorate of economics Statistics, http: /www.agriccoop.nic.in.

Anonymous APEDA (2018) Agricultural and Processed Food Products Export Development Authority

Anonymous. (2018-19). Statistics, ICARIIWBR- Indian Institute of Wheat and Barley Research www.iiwbr.org.

Agrawal, SB, Singh, Anoop, and Dwivedi, Gaurav, 2010. Effect of vermicompost, Farm Yard manure and Chemical Fertilizers on growth and yield of wheat (Triticum aestivum L var HD 2643). Plant Archives 3(1), 9-14.

Aulakh, C.S. 2018. Evaluation of nutrient sources for organic production of rice (Oryza sativa)- wheat (Triticum aestivum) cropping system in northwest India. Indian Journal of Agronomy 63 (2): 137-144.

Channabasanagowda, N. K., Patil, B., Patil, B.N. and Awaknavar, J.S. 2008. Effect of organic manures on growth, seed yield and quality of wheat. Karnataka Journal of Agricultural Sciences.21(3):366-368.

Davari, M.R. Sharma, S.N. and Mirzakhani, M. 2007. The effect of combinations of organic materials and biofertilisers on productivity, grain quality, nutrient uptake and economics in organic farming of wheat (Triticum aestivum). Journal of Organic system 7(2) 26-35.

Gurwinder, S., Santosh, K., Gurjagdeep S.S. and Ramandeep, K. 2018. Effect of integrated nutrient management on yield of wheat (Triticum aestivum L.) under irrigated conditions, International
Journal of Chemical Studies. 6(2): 904907.

Neelam, R.K., Nanwal and Pawan, K. 2015 Effect of organic and inorganic sources of nutrients on productivity and profitability of mungbean-wheat cropping system Legume Research, 38(4): 509-512.

Pagar, R.D., Jangilwad, B.D. and Chaudhary, K.M. 2016. Effect of Panchagavya on Growth and Yield of Wheat (Triticum aestivum L.). Advances in Life Sciences 5(3): 756-760.

Papen, H., Gabler, A., Zumbusch, E. and Rennenberg, H. 2002. Chemo litho autotrophic nitrifiers in the phyllosphere of a Spruce ecosystem receiving high nitrogen input. International Journal of Current Microbiology and Applied Sciences 44: 56-60.

Patel, R.M., and Upadhyay, P.N.1993. Response of wheat to irrigation under varying levels of nitrogen and phosphorous. Indian Journal of Agronomy 38: 113-114.

Sandeep, K., and Thomas, A. 2018. Productivity Potential of Wheat under Certified Organic Production System. International Journal of Current Microbiology and Applied Sciences 7(10): 281-288.

Sanjutha S., Subramanian S., Indu Rani C. and Maheswari J. 2008. Integrated Nutrient Management in (Andrographis paniculate) Research journal of Agriculture and Biological sciences 4(2): 141-145.

Simsek-Ersahin, Y. 2011. The Use of Vermicompost Products to Control Plant Diseases and Pests. In: Karaca A (ed) Biology of Earthworms, Soil Biology Springer-Verlag Berlin Heidelberg.

Sinha, R.K., Herat, S., Valani, D., Chauhan, K. 2009. Vermiculture and sustainable agriculture. American-Eurasian Journal 
of Agricultural and Environmental Sciences 5: 01-55.

Suhane, R.K., Sinha, R.K., Singh, P.K. 2008. Vermicompost, cattle dung compost and chemical fertilizers: Impact on yields of wheat crops. Communication of Rajendra Agriculture University, Pusa, Bihar, India.

Swaminathan, C., Swaminathan, V. and
Vijayalakshmi, K. 2007. Panchagavya: Boon to organic farming. International Book, Distributing Co., Lucknow.

Tamim Fazily, C.S. Hunshal, 2010. Effect of Organic Manures on Yield and Economics of Late Sown Wheat (Triticum aestivum). International Journal of Research and Review. 6(1) 168-171.

\section{How to cite this article:}

Shiva Kumar, M., Rajesh Singh and Punnam Chhetri. 2020. Agronomic Evaluation of Wheat (Triticum aestivum L.) Under Certified Organic Production System. Int.J.Curr.Microbiol.App.Sci. 9(12): 1684-1691. doi: https://doi.org/10.20546/ijcmas.2020.912.200 